\title{
Does occupational exposure to iron promote infection?
}

\author{
Keith Palmer, David Coggon
}

\begin{abstract}
Introduction
Siderosis, the accumulation of ferric oxide particles in the lung, was first described by Zenker over a century ago. ${ }^{1}$ Enquiries subsequently focused on the effect of this pneumoconiotic process on lung function, generally concluding that it was benign. ${ }^{2}$ More recently however, it has become apparent that iron influences bacterial virulence and has a role in host defence against infection. The evidence accrued is sufficient to trigger a reappraisal of health risks in occupational groups exposed to iron. This paper reviews some of the evidence linking iron with infection, and considers what information exists on risk in the occupational setting.
\end{abstract}

IRON IN BIOLOGICAL SYSTEMS

Fifty years ago Schade and Caroline discovered that iron binding proteins, present in blood and the whites of eggs, could inhibit bacterial growth in vitro. ${ }^{4}$ They hypothesised that the proteins they had discovered bound iron so tightly that bacteria could not obtain enough of it to support growth - an effect they were able to abolish by adding extra iron. Later on, others showed that animals injected with iron were more susceptible to infection than untreated controls, and that the well known antibacterial effects of body fluids could be abolished in vitro by adding iron. ${ }^{6-8}$

As Schade and Caroline suggested, a check is placed on growth of pathogens because the amount of free iron available to them in the body fluids of humans and animals is extremely limited. Most of the body's iron stores are intracellular-in ferritin, haemosiderin or haem; and the extracellular fraction is bound to high affinity iron binding proteins - transferrin in serum and lactoferrin in external secretions. ${ }^{9}$ These proteins have large association constants, and are only partially saturated under normal circumstances (30\% to $40 \%$ in the case of serum transferrin), so the amount of free iron in equilibrium with iron binding proteins is thought to be as low as $10^{-18} \mathrm{M}^{10}$

This arrangement makes sense. The ease with which iron undergoes changes in its oxidative state by electron transfer makes it an ideal biological catalyst, essential in the life processes of prokaryotes, eukaryotes, and anaerobic, photosynthetic, and nitrogen-fixing life forms, ${ }^{11}$ but also a focus for potentially injurious free radical formation. Under physi- ological conditions ferric iron tends to oxidise, hydrolyse, and polymerise, forming relatively insoluble ferric hydroxide and oxyhydroxide polymers. ${ }^{10}$ The absorption, transfer, and delivery of iron is tightly controlled at every stage, to ensure that it remains available in a soluble, non-toxic form. Commensal microorganisms and microbial pathogens are therefore thought to exist in an iron restricted environment.

\section{THE BATTLE FOR FREE IRON}

There is evidence that pathogens adapt in a variety of ways to obtain the iron they need-for example, by producing their own low molecular weight iron chelators, by modifications to their outer membrane proteins, and by the elaboration of haemolysins which liberate iron from haem. ${ }^{12}$ Host organisms counter this by restricting iron availability during infection. Additional iron binding capacity may be recruited in inflammatory exudate, as polymorphonuclear leucocytes degranulate, releasing lactoferrin; ${ }^{13}{ }^{14}$ while the amount of iron bound to serum transferrin falls (the hypoferraemia of infection) by a mechanism that may entail lactoferrin release, macrophage sequestration of $\mathrm{Fe}^{3+}$-transferrin complexes, and increased synthesis of ferritin. ${ }^{15}$ Dietary iron assimilation is suppressed by as much as $80 \%$; and iron efflux from macrophages that have digested effete red blood cells is reduced by as much as $70 \%{ }^{16}$

Other interactions between organism and host may also operate, including the host's immune response to foreign iron sequestering proteins, and the proteolytic cleavage of transferrin and lactoferrin by certain bacteria. ${ }^{16}$ The essential point is that a critical balance exists between commensal or pathogen and host in the fight for available iron. The normal flora of the respiratory tract reflect in part the nutrient limited balance so achieved. In situations where the balance is disturbed, as for example when exogenous or endogenous supplies of iron exceed the capacity of the iron binding protein system, overgrowth of organisms may be encouraged.

Similar considerations may apply in viral infection: although viruses do not require iron, the host cells they infect need iron before viral replication can occur, and the hypoferraemia of infection has been found in children infected with mumps and chickenpox. ${ }^{17}$ 
Table 1 Mortality from respiratory illness among men in metal working occupations in England and Wales: 1930-2, 1949-53, 1959-63, 1970-2, and 1979-80/82-90

\begin{tabular}{|c|c|c|c|c|c|c|c|c|c|c|}
\hline \multirow{3}{*}{$\begin{array}{l}\text { Underlying } \\
\text { cause of } \\
\text { death }\end{array}$} & \multirow[b]{3}{*}{ Exposure group } & \multicolumn{3}{|l|}{$1930-2$} & \multicolumn{3}{|l|}{$1949-53$} & \multicolumn{3}{|l|}{ 1959-63 } \\
\hline & & \multicolumn{3}{|c|}{ Ages 20-65 } & \multicolumn{3}{|c|}{ Ages 20-64 } & \multicolumn{3}{|c|}{ Ages 15-64 } \\
\hline & & $\begin{array}{l}\text { Deaths } \\
\text { observed }\end{array}$ & $S M R$ & $(95 \% C I)$ & $\begin{array}{l}\text { Deaths } \\
\text { observed }\end{array}$ & $S M R$ & $(95 \% C I)$ & $\begin{array}{l}\text { Deaths } \\
\text { observed }\end{array}$ & $S M R$ & $(95 \% C I)$ \\
\hline \multirow[t]{3}{*}{ Pneumonia } & Metal fume (definite) $†$ & 285 & 167 & (148 to 187 ) & 198 & 189 & (164 to 218 ) & 225 & 194 & (169 to 221 ) \\
\hline & Metal fume (possible) $\ddagger$ & 254 & 158 & (139 to 179$)$ & 139 & 147 & (124 to 174$)$ & 140 & 121 & (101 to 142$)$ \\
\hline & Metal dust $\S$ & 111 & 174 & (143 to 209 ) & 34 & 130 & (90 to 182 ) & 28 & 119 & (79 to 172 ) \\
\hline \multirow[t]{3}{*}{ Influenza } & Metal fume (definite) $†$ & 101 & 133 & (108 to 161$)$ & 69 & 161 & (125 to 204$)$ & 39 & 125 & (89 to 171 ) \\
\hline & Metal fume (possible) $\ddagger$ & 77 & 131 & (103 to 163$)$ & 58 & 163 & (124 to 211$)$ & 28 & 96 & (67 to 138$)$ \\
\hline & Metal dust $\int$ & 24 & 103 & (66 to 153$)$ & 18 & 196 & (116 to 310$)$ & 11 & 161 & (80 to 288 ) \\
\hline \multirow[t]{3}{*}{ Bronchitis ${ }^{\star \star}$} & Metal fume (definite) $\dagger$ & 118 & 173 & (143 to 207 ) & 384 & 169 & (152 to 187 ) & 459 & 154 & (140 to 169$)$ \\
\hline & Metal fume (possible) $\ddagger$ & 83 & 115 & (92 to 142$)$ & 289 & 116 & (103 to 130$)$ & 307 & 100 & (89 to 112 ) \\
\hline & Metal dust $\S$ & 48 & 184 & (136 to 244$)$ & 87 & 106 & (87 to 130$)$ & 72 & 109 & (85 to 137 ) \\
\hline
\end{tabular}

The data are derived from the Registrar General's decennial supplements, England and Wales for the relevent periods. ${ }^{32-36}$ For $1979-80$ and $1982-90$ the PMRs are standardised for both age and social class; for earlier periods the PMRs and SMRs are standardised for age, and adjusted for social class by multiplying expected numbers of deaths by the the cause and social class specific PMR or SMR for men of the relevent age group.

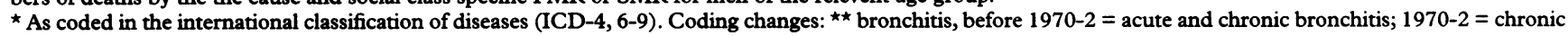
bronchitis, emphysema, and asthma (ICD-8 490-3); 1979-80, 1982-90 = chronic bronchitis and emphysema (ICD-9 491-2, 496).

OTHER MECHANISMS OF ACTION

Apart from its role as a nutrient for pathogens, there are other possible ways in which iron could promote infection, especially respiratory tract infection. Iron may be implicated through a mechanism of free radical injury: in vivo iron dependent reduction of hydrogen peroxide generates hydroxyl radicals, the toxic properties of which have recently been reviewed. ${ }^{18}$ Studies have shown that metal particles, or carbon coated with metals, can be cytotoxic to macrophages, ${ }^{19} 20$ and short term inhalation experiments in animals have produced a cytotoxic response at ambient concentrations down to $0.1 \mathrm{mg} / \mathrm{m}^{3}{ }^{39}$ Factors that interfere with the efficiency of phagocytosis are liable to render the host more susceptible to infection, independent of any effect on the nutrient status of the pathogen.

\section{EXCESS IRON IN VIVO}

Observations on iron overload in vivo are generally consistent with the in vitro experimental data. In clinical situations where the availability of free iron is increased, a propensity to infection has been described-for example, patients with sickle cell disease who release free iron in haemolytic crises, seem to be more susceptible to infection, particularly pneumonia ${ }^{21}$ and pneumoccocal infection, ${ }^{22}$ patients with haemochromatosis, who absorb excessive quantities of iron from dietary sources are prone to infection with Vibrio species, ${ }^{23}$ accidental iron overdose has been linked with bacterial septicaemia ${ }^{24}$ and meningitis, ${ }^{25}$ low concentrations of unsaturated transferrin have been associated with high fatality in pneumoccocal pneumonia, ${ }^{26}$ and lactoferrin deficiency has been described in the polymorph granules of a patient with repeated deep seated abscesses. ${ }^{27}$

These and other clinical consequences of excess iron have been reviewed recently. ${ }^{28}$

\section{Occupational exposure to iron}

SOURCES OF EXPOSURE

Occupational exposure to iron arises mainly from work that generates metal fume or metal dust. Occupations associated with metal fume include gas and electric welders, cutters and braziers; furnacemen in foundries and iron and steel production; and foundry moulders and core makers, who in smaller foundries also pour and cast molten metals. Exposure to metal fume may also occur, although to a lesser extent, in foundry and steel-mill labourers, and in sheet metal workers, who sometimes cut metal sheets with welding apparatus. Occupations that may incur exposure to iron dust include: fettlers, metal polishers, boiler scalers, and workers engaged in the mining, crushing, milling, and mixing of iron ores.

The occurrence of siderosis in several of these groups, such as welders, fettlers, dressers, boiler scalers, and iron ore miners ${ }^{3}$ attests to considerable degrees of iron exposure. In 1955-60 the prevalence of siderosis among welders and burners in the fettling and grinding shops of a Sheffield foundry was found to be $17.6 \% ;^{29}$ others too have reported its frequent occurrence.

Commonly the occupational exposure is to ferric oxide, although in the case of welding the fume is more complex $(20 \%-90 \%$ is crystalline, especially as $\mathrm{Fe}_{3} \mathrm{O}_{4}$, but it also contains other compounds, including fluorides of sodium and calcium, carbonates of sodium and potassium, magnesium oxide, and $\mathrm{MnFe}_{2} \mathrm{O}_{4}$ ). In metal mining the main ores are haematite and magnetite.

\section{Lung responses to iron overload}

The lung's response to excessive iron may include the liberation of iron binding protein, extra macrophage uptake, and ferritin formation. Interestingly, simulated welding exercises provoke a considerable increase in the polymorphonuclear count in bronchoalveolar lavage fluid, together with a release of cytokines, including TNF, $\mathrm{IL}-1$, and $\mathrm{IL}-6 .{ }^{30}$ Perhaps this inflammatory cellular response leads to the release of lactoferrin and the sequestration of free iron, as the IL-1 response in infection has been linked with the hypoferraemia of infection. ${ }^{28}$

In any case, the response is not always complete or adequate. In siderosis ferric oxide particles have been found extravascularly, in the 


\begin{tabular}{|c|c|c|c|c|c|c|c|c|c|c|c|}
\hline \multicolumn{6}{|l|}{$1970-72$} & \multicolumn{6}{|c|}{$1979-80$ and $1982-90$} \\
\hline \multicolumn{3}{|c|}{ Ages 15-64 } & \multicolumn{3}{|c|}{ Ages 65-74 } & \multicolumn{3}{|c|}{ Ages 20-64 } & \multicolumn{3}{|c|}{ Ages 65-74 } \\
\hline $\begin{array}{l}\text { Deaths } \\
\text { observed }\end{array}$ & $S M R$ & $(95 \% C I)$ & $\begin{array}{l}\text { Deaths } \\
\text { observed }\end{array}$ & $P M R$ & $(95 \% C I)$ & $\begin{array}{l}\text { Deaths } \\
\text { observed }\end{array}$ & $P M R$ & $(95 \% C I)$ & $\begin{array}{l}\text { Deaths } \\
\text { observed }\end{array}$ & $P M R$ & $(95 \% C I)$ \\
\hline 131 & 186 & (156 to 221 ) & 169 & 129 & (110 to 149 ) & 214 & 163 & (142 to 186$)$ & 325 & 107 & (95 to 119 ) \\
\hline 73 & 144 & (113 to 181 ) & 109 & 114 & (93 to 137) & 101 & 112 & (91 to 136$)$ & 239 & 98 & (86 to 112 ) \\
\hline 19 & 131 & (79 to 205 ) & 30 & 145 & (98 to 207 ) & 36 & 164 & (114 to 227 ) & 75 & 108 & (85 to 136$)$ \\
\hline 34 & 221 & (153 to 308 ) & 23 & 117 & (74 to 175 ) & 3 & 98 & (20 to 285 ) & 3 & 55 & (11 to 159 ) \\
\hline 14 & 135 & (74 to 226 ) & 13 & 98 & (52 to 167 ) & 0 & 0 & (0 to 175 ) & 5 & 114 & (37 to 265 ) \\
\hline 3 & 103 & (21 to 302$)$ & 2 & 65 & (8 to 233 ) & 0 & 0 & (0 to 805 ) & 0 & 0 & (0 to 318 ) \\
\hline 265 & 164 & (144 to 185 ) & 353 & 133 & (119 to 147$)$ & 388 & 117 & (106 to 130$)$ & 947 & 124 & (116 to 132$)$ \\
\hline 129 & 118 & (98 to 140$)$ & 214 & 114 & (100 to 131 ) & 236 & 111 & (97 to 126$)$ & 558 & 101 & (93 to 110$)$ \\
\hline 42 & 128 & (92 to 173 ) & 54 & 136 & (102 to 178$)$ & 72 & 128 & (100 to 161$)$ & 227 & 134 & (117 to 153 ) \\
\hline
\end{tabular}

† Welders, moulders and coremakers, and foundry furnacemen.

$¥$ Foundry labourers, sheet metal workers, tin platers, and galvanisers.

$\int$ For $1930-2=$ metal grinders, cutlery grinders, file cutters, filers, metal glazers, polishers, buffers, and moppers. For $1949-53=$ edge tool grinders, file cutters, filers, metal glazers, polishers, buffers, and moppers. For 1959-63 and 1970-2 = fettlers, and metal dressers. For $1979-80$ and $1982-90=$ fettlers, metal dressers, and polishers.

alveolar walls and spaces. Some of the iron is stored as ferritin, and so stains with Perl's Prussian blue, but much of it does not. ${ }^{2}$ This confirms a situation of iron overload. It should be noted in this context that even a partial increase in iron saturation may make iron more freely available to some well adapted pathogens. ${ }^{28}$

What factors are likely to determine the type and magnitude of effect? As in other occupational exposures, dose is important, but the relative importance of intensity and duration of exposure is not clear. Perhaps brief peaks of exposure matter in relation to short term adaptive responses in the host, whereas the outcome of long term exposure depends upon the lung's adaptive reserves.

Particle size may influence local dose and delivery site. Two different methods of particle generation are in operation occupationallycondensation of heated metal fume to produce very fine particulate metal oxides, and abrasion and dispersion of iron bearing materials to produce somewhat larger iron laden dusts. It might be supposed that these mechanisms result in different patterns of deposition and different clinical effects. In practice, however, there is overlap: metal oxide condensates in metal fume tend to aggregate and grow and to deposit in large as well as small airways, whereas the occurrence of siderosis and alveo- lar iron in the dust generating professions confirms that these actvities can also produce considerable numbers of fine particles.

The effect may also depend on host susceptibility and a multiplicity of host defence factors - some related to iron (including differences in iron body stores and iron binding capacity) and some not. Constitutional factors, nutrition, pre-existing disease, and cigarette and alcohol intake are all likely to play a part. Finally, the outcome may depend upon the resident microbial population. For example, workers with chronic bronchitis who have a permanent reservoir of pathogens in their bronchi may be at different risk from other healthier workers.

To date interest has mainly focused on the role of endogenous and dietary iron in infection, but some occupational data exist that provide information on the relation between exogenous respirable iron and infective illness.

\section{Epidemiology}

OCCUPATIONAL MORTALITY

Direct evidence that occupational exposure to iron increases susceptibility to infection comes mainly from routinely published analyses of occupational mortality. Coggon et a $\mathcal{l}^{11}$ recently conducted an analysis of mortality from pneumonia in populations exposed to metal fumes, with data abstracted from the Registrar Gener-

Table 2 Mortality from non respiratory infectious diseases among men in metal working occupations in England and Wales, 1979-80 and 1982-90

\begin{tabular}{|c|c|c|c|c|c|c|c|c|c|c|c|c|}
\hline \multirow[b]{3}{*}{ Underlying cause of death* } & \multicolumn{6}{|c|}{$\begin{array}{l}\text { Welders, moulders and coremakers, furnacement (definite fume } \\
\text { exposure) }\end{array}$} & \multicolumn{6}{|c|}{$\begin{array}{l}\text { Foundry labourers, sheet metal workers, tin platers, and } \\
\text { galvanisers (possible fume exposure) }\end{array}$} \\
\hline & \multicolumn{3}{|c|}{ Age $20-64$} & \multicolumn{3}{|c|}{ Age $65-74$} & \multicolumn{3}{|c|}{ Age $20-64$} & \multicolumn{3}{|c|}{ Age $65-74$} \\
\hline & Deaths & $P M R$ & $(95 \% C I)$ & Deaths & $P M R$ & $(95 \% C I)$ & Deaths & PMR & $(95 \% C I)$ & Deaths & $P M R$ & $(95 \% C I)$ \\
\hline $\begin{array}{l}\text { All non-respiratory infections: } \\
\text { Viral infections other than }\end{array}$ & 37 & 98 & (69 to 136$)$ & 26 & 93 & $(60$ to 136$)$ & 24 & 109 & (70 to 162$)$ & 16 & 81 & (46 to 131 ) \\
\hline influenza $(045-57,060-6,070-9)$ & 7 & 71 & (29 to 147$)$ & 3 & 96 & (20 to 281 ) & 10 & 178 & $(85$ to 328$)$ & 2 & 97 & (12 to 351 ) \\
\hline CNS infections (320-4) & 7 & 109 & (44 to 225 ) & 5 & 163 & (53 to 380 ) & 4 & 93 & ( 25 to 239 ) & 1 & 44 & (1 to 242 ) \\
\hline Infections of the kidney; cystitis & & & & & & & & & & & & \\
\hline$(510,595)$ & 8 & 138 & (60 to 272 ) & 14 & 138 & (75 to 231 ) & 3 & 73 & (15 to 212 ) & 5 & 65 & ( 21 to 152 ) \\
\hline Septicaemia(038) & 7 & 104 & (42 to 214 ) & 5 & 76 & (25 to 177 ) & 1 & 29 & (1 to 159 ) & 4 & 95 & (26 to 242 ) \\
\hline Cancer of the lung and pleura (162): & 1328 & 110 & (104 to 116$)$ & 1591 & 112 & (107 to 118$)$ & 727 & 107 & (99 to 115 ) & 1051 & 110 & (103 to 117 ) \\
\hline
\end{tabular}

The data are derived from information provided by OPCS on deaths among men aged 20-74 in England and Wales during 1979-80 and 1982-90. PMRs are standardised for both age and social class.

* Code numbers refer to the ICD-9.

t Occupations as defined in occupational health decennial supplement series DS No 10 1995, appendix $3 .^{34}$ 
Table 3 Mortality from respiratory infective illnesses in working aged men from ferrous and non-ferrous metal working occupations in England and Wales, 1930-32 and 1949-53

\begin{tabular}{|c|c|c|c|c|c|c|}
\hline \multirow[b]{3}{*}{ Occupational groups* } & \multicolumn{6}{|l|}{ Influenza } \\
\hline & \multicolumn{3}{|c|}{$\begin{array}{l}1930-2 \\
\text { ages } 20-65\end{array}$} & \multicolumn{3}{|c|}{$\begin{array}{l}1949-53 \\
\text { ages } 20-64\end{array}$} \\
\hline & $\begin{array}{l}\text { Observed } \\
\text { deaths }\end{array}$ & $S M R$ & $(95 \% C I)$ & $\begin{array}{l}\text { Observed } \\
\text { deaths }\end{array}$ & $S M R$ & $(95 \% C I)$ \\
\hline Ferrous moulders & 60 & 145 & (111 to 187 ) & 25 & 172 & (111 to 254 ) \\
\hline Brass moulders & 6 & 106 & (39 to 232 ) & 3 & 103 & (21 to 301$)$ \\
\hline $\begin{array}{l}\text { Ferrous furnacemen; iron and steel } \\
\text { foundry labourers }\end{array}$ & 76 & 158 & (124 to 197$)$ & 54 & 216 & (162 to 282 ) \\
\hline $\begin{array}{l}\text { Non-ferrous foundry workers } \\
\text { (furnacemen and labourers) }\end{array}$ & 4 & 96 & (26 to 247 ) & 3 & 100 & (21 to 291 ) \\
\hline Iron ore miners & 8 & 284 & (122 to 559$)$ & - & - & - \\
\hline $\begin{array}{l}\text { Miners of tin, copper and other } \\
\text { metalliferous ores }\end{array}$ & 2 & 106 & (13 to 384 ) & - & - & - \\
\hline
\end{tabular}

The data are derived from the Registrar General's decennial supplements, England and Wales for the relevent periods. ${ }^{35}{ }^{36}$ All SMRs are standardised for age, and adjusted for social class by multiplying expected numbers of deaths by cause and social class specific SMR for men of the relevent age group.

al's decennial supplements for the periods $1959-63^{32}$ and $1970-72 ;^{33}$ and information provided by the Office of Population, Censuses and Surveys (OPCS) on deaths among men aged 20-74 in England and Wales during $1979-80$ and $1980-90 .^{34}$

In the decennial supplements, expected numbers of deaths for each occupation in men of working age were calculated by applying five year age specific death rates for pneumonia in the general population to an estimate of the occupational population derived from the national census in the middle year of the study period (1961 or 1971). The relation of observed to expected deaths was expressed as a standardised mortality ratio (SMR). The report for 1970-2 also presented proportional mortality ratios (PMRs) for the age range 65-74 years, with expected numbers of deaths derived by applying age specific proportions of death from pneumonia in the general population to the total number of deaths at each age in the occupational population. Death reports for 1979-80 and 1982-90 were used to derive PMRs for pneumonia by occupation, standardised for age in five year strata and for social class (SMRs could not be calculated as the population denominators for this period were not available).

The analysis showed a consistently increased mortality from pneumonia in occupations involving exposure to metal fume, and particularly in welders, moulders, and coremakers. The largest excess of deaths was for lobar pneumonia, but increases were also found for other subcategories with the exception of bronchopneumonia. Moreover, the higher risk was restricted to men below retirement age, suggesting a short term, reversible effect of exposure.

Table 1 extends these observations with added data derived from the Registrar General's supplements for $1930-2^{35}$ and $1949-53 .^{36}$ Only SMRs were published for this period. In table 1 we have grouped occupations with potential exposure to metal fume into those in which exposure is definite (welders, moulders and coremakers, and foundry furnacemen), and those where it is possible (foundry labourers, sheet metal workers, tin platers, and galvanisers); included a group of workers with defi- nite metal dust exposure (metal polishers and fettlers); and examined influenza and bronchitis as other causes of death that might also be influenced by iron exposure. The data for 1979-80 and 1981-90 have been standardised for age and social class, and those for earlier periods standardised for age, and adjusted for social class by multiplying the expected numbers of deaths by the corresponding cause and social class specific PMR or SMR.

As in previous analyses, occupations with potential exposure to metal fume, and particularly welders, moulders, coremakers, and furnacemen, had significantly increased mortality from pneumonia. Excesses were also apparent for metal grinders and polishers, although they were less obvious. The pattern for influenza (deaths from which may result from secondary bacterial pneumonia ${ }^{37}{ }^{38}$ ) was broadly similar, although by the 1980 s there were too few deaths observed and expected for meaningful interpretation. Occupations entailing exposure to metal fume and dust also tended to have increased mortality from bronchitis and again the highest rates were in welders, moulders, coremakers, and furnacemen.

As previously noted, the excess mortality from pneumonia in occupations with exposure to metal fume has been confined to men of working age. This makes confounding by smoking and other non-occupational factors an unlikely explanation. In further support of this, the occupations do not have comparable excesses of lung cancer (table 2), nor is their mortality from non-respiratory infections increased.

These findings support the hypothesis that inhalation of metal fume and dust promotes respiratory infection, but they do not indicate whether the effect is specific to iron. A test of this is provided by data from 1930-2 and 1949-53 when (by contrast with later reports) workers in ferrous foundries were distinguished from foundrymen working other metals, and iron ore miners from miners of tin, copper and other metalliferous ores (table 3 ). The increase of mortality from pneumonia and influenza was generally more obvious in those working with ferrous metal, but no consistent differences were apparent in mortality from bronchitis. Similarly, in 1910-2 the risk of 


\begin{tabular}{|c|c|c|c|c|c|c|c|c|c|c|c|}
\hline \multicolumn{6}{|c|}{ Pneumonia } & \multicolumn{6}{|l|}{ Bronchitis } \\
\hline \multicolumn{3}{|c|}{$\begin{array}{l}1930-2 \\
\text { ages } 20-65\end{array}$} & \multicolumn{3}{|c|}{$\begin{array}{l}1949-53 \\
\text { ages } 20-64\end{array}$} & \multicolumn{3}{|c|}{$\begin{array}{l}1930-2 \\
\text { ages } 20-65\end{array}$} & \multicolumn{3}{|c|}{$\begin{array}{l}1949-53 \\
\text { ages } 20-64\end{array}$} \\
\hline $\begin{array}{l}\text { Observed } \\
\text { deaths }\end{array}$ & $S M R$ & $(95 \% C I)$ & $\begin{array}{l}\text { Observed } \\
\text { deaths }\end{array}$ & $S M R$ & $(95 \% C I)$ & $\begin{array}{l}\text { Observed } \\
\text { deaths }\end{array}$ & $S M R$ & $(95 \% C I)$ & $\begin{array}{l}\text { Observed } \\
\text { deaths }\end{array}$ & $S M R$ & $(95 \% C I)$ \\
\hline $\begin{array}{r}158 \\
22\end{array}$ & $\begin{array}{l}191 \\
173\end{array}$ & $\begin{array}{l}\text { (162 to } 223) \\
\text { (108 to } 261)\end{array}$ & $\begin{array}{r}68 \\
6\end{array}$ & $\begin{array}{r}190 \\
73\end{array}$ & $\begin{array}{r}(147 \text { to } 240) \\
(27 \text { to } 158)\end{array}$ & $\begin{array}{l}59 \\
12\end{array}$ & $\begin{array}{l}180 \\
220\end{array}$ & $\begin{array}{l}(137 \text { to } 232) \\
\text { (114 to } 384)\end{array}$ & $\begin{array}{r}171 \\
29\end{array}$ & $\begin{array}{l}205 \\
164\end{array}$ & $\begin{array}{l}\text { (176 to } 238) \\
(110 \text { to } 236)\end{array}$ \\
\hline 237 & 171 & (150 to 195 ) & 120 & 188 & (156 to 225 ) & 78 & 124 & (98 to 154 ) & 244 & 173 & (152 to 196 ) \\
\hline $\begin{array}{l}24 \\
20\end{array}$ & $\begin{array}{l}213 \\
200\end{array}$ & $\begin{array}{l}(136 \text { to } 317) \\
\text { (122 to } 309)\end{array}$ & $\begin{array}{l}6 \\
-\end{array}$ & 66 & $\begin{array}{c}\text { (24 to } 144) \\
-\end{array}$ & $\begin{array}{l}5 \\
4\end{array}$ & $\begin{array}{l}90 \\
110\end{array}$ & $\begin{array}{l}(29 \text { to } 210) \\
(30 \text { to } 281)\end{array}$ & $\begin{array}{r}29 \\
-\end{array}$ & $\begin{array}{l}145 \\
-\end{array}$ & $\begin{array}{l}\text { (97 to } 208 \text { ) } \\
-\end{array}$ \\
\hline 5 & 110 & (36 to 256 ) & - & - & - & 4 & 220 & (60 to 563 ) & - & - & - \\
\hline
\end{tabular}

* Occupation codes: 1930-2 ferrous moulders 151-2; brass moulders 150; ferrous foundry furnacemen and labourers 140-2,149,153-4; brass and bronze furnacemen and labourers 155-6: 1949-53 ferrous moulders 132; brass moulders 131; iron and steel foundry furnacemen and iron foundry labourers 121,122/ 5,134-5 non-ferrous foundry furnacemen and labourers $137-8$.

death from pneumonia in iron founders was twice that in brass founders, and that in iron miners and quarriers was $50 \%$ greater than in lead miners; but there was no corresponding excess risk of mortality from bronchitis. ${ }^{39} \mathrm{Gen}$ erally, the pattern is compatible with a specific hazard from iron, possibly superimposed on a second hazard from metal fume more generally.

\section{Other studies}

Published cohort studies of mortality in workers exposed to metal fume or dust from iron ore shed little extra light on the topic. In general these have not looked specifically at infective risk, and have lacked sufficient statistical power to answer this particular question. Where excess mortality from respiratory disease has been described, often the data have not been broken down by cause, ${ }^{40}{ }^{41}$ although in two large studies excesses of pneumonia were apparent, with SMRs of 185 and 167 among welders in the north east of England and in Seattle, United States. ${ }^{42}{ }^{43}$ An association has also been described between work in ferrous foundries and death from chronic bronchitis. ${ }^{44}$ By contrast a large European study of 11000 welders failed to show an excess of pneumonia, or of bronchitis, emphysema, or asthma, ${ }^{45}$ and no excesses were found in a cohort of iron ore miners from Minnesota. ${ }^{46}$

Morbidity from infective illness in metal workers has been studied even less than mortality. An analysis of hospital admissions among American shipyard workers during $1942-5^{47}$ and a cross sectional survey of British shipyard employees ${ }^{48}$ indicated no relation between pneumonia and exposure to metal fume; but in a survey of certified sickness absence during a 10 year period, four of 36 welders had absences attributed to pneumonia compared with none of a similar number of controls. ${ }^{49}$ A number of cross sectional studies have failed to find an excess of chronic bronchitis in welders, ${ }^{50} 51$ but many studies have identified an excess of current cough and sputum in active workers, independent of smoking. ${ }^{48}$ Furthermore, a recent longitudinal study has described an enhanced deterioration in lung function in welders which was also independent of smoking. ${ }^{52}$

\section{Conclusions}

A growing body of evidence suggests that free iron in body fluids promotes bacterial growth. In theory, therefore, occupations that entail exposure to iron fume or dust could carry an increased risk of infection. The principal data that allow a test of this come from national statistics of occupational mortality, and are subject to several well documented biases. In particular, the derivation of SMRs depends on occupational codings for the numerator and denominator that come from different sources (death certificates and censuses respectively); whereas PMRs, although derived from a single source (death certificates), may mislead if overall mortalities in an occupation are unusually high or low. There are other limits to the data - for example, scope for exposure misclassification if the job reported for death certification is inaccurate or ill defined; changes over time in diagnostic practice and classification; and in some analyses small numbers of observed deaths and correspondingly wide confidence intervals. Nor should the potential for confounding by non-occupational factors be ignored. Our findings have been adjusted for age and social class, and we have argued that confounding by smoking is unlikely to explain them, but the increases in relative risk in a number of analyses are comparatively modest, and vulnerable to the effects of unrecognised confounders.

Set against these concerns are the consistency and coherence of effect, apparent through several periods of analysis and for several outcomes. Analyses of occupational mortality indicate that workers exposed to metal fume and dust have high death rates from pneumonia, influenza, and bronchitis, but not from other infections.

Risks have tended to be higher in men working with ferrous compared with other metals, but the difference is not clear cut. Thus, the possibility of a general hazard of metal fumefor example, from impairment of macrophage function-cannot be ruled out. Nevertheless, the specific role of iron merits further investigation. An early priority is to establish whether exposure to metal fume is associated with a higher incidence of respiratory infection as well as a higher mortality, and whether the associ- 
ation is with all types of metal or only with iron. It would also help to know more about the fate of inhaled iron fume, and particularly what proportion remains unbound, for how long, and at what sites in the lung.

We thank Paul Winter and Hazel Inskip for their assistance in data analysis, and Christopher Martyn and Keith Godfrey for their constructive comments.

1 Zenker FA. Ueber Staublinhalationskrankheiten der lung Deutsch Arch Klin Med 1866;2:116.

2 Morgan WKC. Other pneumoconioses. In: Morgan WKC Seaton MD, eds. Occupational lung diseases. Philadelphia: WB Saunders, 1975:235-40

3 Parkes WR. Inert dusts. In: Parkes WR. Occupational lung disorders. 2nd ed. London: Butterworth, 1982:113-7.

4 Schade AL, Caroline L. Raw hen egg white and the role of iron in growth inhibition of Shigella dysenteriae, Staphylococcus aureus, Escherichia coli, and Saccharomyces cerevisiae. Science 1944;100:14-5.

5 Schade AL, Caroline L. An iron binding component in human blood plasma. Science 1946;104:340-1.

6 Bullen JJ. The significance of iron in infection. Reviews of Infectious Diseases 1981;3:1127-38.

7 Finkelstein RA, Sciortino CV, McIntosh MA. Role of iron in microbe-host interactions. Reviews of Infectious Diseases microbe-host in

8 Weinberg ED. Iron with-holding: a defense against infection and neoplasia. Physiol Rev 1984;64:65-102.

9 Bezkorovainy A. Iron proteins. In: Bullen JJ, Griffiths E, eds Iron and infection: physiological and clinical aspect Chichester: John Wiley, 1987:27-67.

10 Bullen JJ, Rogers HJ, Griffiths E. Role of iron in bacteria infection. Curr Top Microbiol Immunol 1978;80:1-35.

11 Jacobs A, Worwood M. Iron in biochemistry and medicine. London: Academic Press, 1980.

12 Griffiths E. The iron-uptake systems of pathogenic bacteria In: Bullen JJ, Griffiths E, eds. Iron and infection: physiological In: Bullen JJ, Griffiths E, eds. Iron and infection: physiological
and clinical aspects. Chichester: John Wiley, 1987:69-137.

13 Leffell MS, Spitznagel JK. Fate of human lactoferrin and myeloperoxidase in phagocytizing human neutrophils: effects of immunoglobulin $G$ subclasses and immune complexes coated on latex beads. Infect Immun 1975;12:813 20 .

14 Klempner MS, Dinarello CA, Gallin JI. Human leukocyte pyrogen induces release of specific granule contents from human neutrophils. $\mathcal{7}$ Clin Invest 1978;61:1330-6.

15 Lee GR. The anemia of chronic disease. Semin Hematol 1983;20:61-80

16 Weinburg ED, Weinberg GA. The role of iron in infection Current Opinion in Infectious Diseases 1995;8:164-9.

17 Cemeroglu AP, Ozsoylu S. Haematologic consequences of viral infections including serum iron status. Eur $\mathcal{F}$ Pediatr 1994;153:171-3.

18 Herbert V, Shaw S, Jayatilleke E, Stopler-Kasdan T. Most free-radical injury is iron-related: it is promoted by iron, hemin, holoferritin and vitamin C, and inhibited by desferoxamine and apoferritin. Stem Cells 1994;12:289-303.

19 Goyer RA. Toxic effects of metals. In: Klaassen CD, Amdur MO, Doull J, eds. Casarett and Doull's toxicology: the basic science of poisons, 3rd ed. New York: Macmillan, 1986:582 635.

20 Schlesinger RB. The interaction of inhaled toxicants with respiratory tract clearance mechanisms. Crit Rev Toxicol respiratory tract

21 Barrett-Connor E. Bacterial infection and sickle cell anaemia. An analysis of 250 infections in 166 patients and a review of the literature. Medicine 1971;50:97-112.

22 Overturf DG, Powers P, Baraff LJ. Bacterial meningitis and septicaemia in sickle cell disease. Am $\mathcal{F}$ Dis Child 1977;131 784-7.

23 Blake PA, Merson MH, Weaver RE, Hollis DG, Heublein PC. Disease caused by a marine Vibrio: clinical characteristics and epidemiology. $N$ Engl f Med 1979;300:1-5.

24 Melby K, Slordahl S, Gutteberg TJ, Nordbo SA. Septicaemia due to Yersinia enterocolitica after oral overdoses of iron. $B M F$ f 1982;285:467-8.

25 Sweder Van Asbeck B, Verbrugh HA, Van Oost BA. Listeria monocytogenes meningitis and decreased phagocytosis monocytogenes meningitis and decreased phagocy
associated with iron overload. BMf 1982;284:542-4.
26 Lambert CC, Hunter RL. Low levels of unsaturated transferrin as a predictor of survival in pneumococcal pneumonia. Ann Clin Lab Sci 1990;20:140-6.

27 Boxer LA, Coates TD, Haak RA, Wolach JB, Hoffstein S, Baehner RL. Lactoferrin deficiency associated with altered granulocyte function. N Engl F Med 1982;303:404-10

28 Kluger MJ. Clinical and physiological aspects. In: Bullen JJ, Griffiths $\mathrm{E}$, eds. Iron and infection: physiological and clinical aspects. Chichester: John Wiley, 1987:243-82.

29 Gregory J. A survey of pneumoconiosis at a Sheffield steel factory. Arch Environ Health 1970;20:385-99.

30 Blanc PD, Boushey HA, Wong H, Wintermeyer SF, Bernstein MS. Cytokines in metal fume fever. Am Rev Respir Dis 1993;147:134-8.

31 Coggon $\mathrm{D}$, Inskip $\mathrm{H}$, Winter $\mathrm{P}$, Pannett $\mathrm{B}$. Lobar pneumonia: an occupational disease in welders. Lancet 1994;344:41-4

32 Registrar General. Decennial supplement England and Wales 1961 occupational mortality tables. London: HMSO, 1971.

33 Registrar General. Decennial supplement England and Wales 1971. London: HMSO, 1981. (Series DS No 1.)

34 Registrar General. Drever F, ed. Occupational health deccenial supplement. London: HMSO, 1995. (Series DS No10.)

35 Registrar General. Decennial supplement England and Wales 1931. London: HMSO, 1938

36 Registrar General. Decennial supplement England and Wales 1951 occupational mortality. Part II, vol 1. London: HMSO 1958.

37 Oseasohn R, Adelson L, Kaji M. Clinicopathologic study of thirty three fatal cases of Asian influenza. $N E n g l \mathcal{F} M e d$ 1959;260:509-18.

38 Lindsay MI Jr, Herrmann EC Jr, Morrow GW Jr, Brown ALJ. Hong Kong influenza - clinical, microbiologic and pathologic features in 127 cases. $\mathscr{F A M A} 1970 ; 214: 1825$ 32.

39 Registrar General. Supplement to the 75th annual report of the Registrar General for England and Wales. Part IV: mortality of men in certain occupations in the three years 1910,1911, and 1912. London: HMSO, 1923.

40 Kinlen LJ, Willows AN. Decline in the lung cancer hazard: a prospective study of the mortality of iron ore miners in Cumbria. Br F Ind Med 1988;45:219-24

41 Sorahan T, Faux AM, Cooke MA. Mortality among a cohort of United Kingdom steel foundry workers with special reference to cancers of the stomach and lung, 1946-90. Occup Environ Med 1994;51:316-22.

42 Newhouse ML, Oakes D, Woolley AJ. Mortality of welder and other craftsmen at a shipyard in NE England. Br F Ind Med 1985;42:406-10.

43 Beaumont JJ, Weiss NS. Mortality of welders, shipfitters and other metal trades workers in boilermakers local no 104 AFL-CI0. Am ₹ Epidemiol 1980;112:775-86

44 Silverstein M, Naizlih N, Park R, Silverstein B, Broadsky L Mirer F. Mortality among ferrous foundry workers. $A m \mathcal{F}$ Ind Med 1986;10:27-43.

45 Simonato L, Fletcher AC, Andersen A, et al. A historica prospective study of European stainless steel, mild steel, and shipyard welders. Br $\mathcal{F}$ Ind Med 1991;48:145-54

46 Lawler AB, Mandel JS, Schuman LM, Lubin JH. A Retrospective cohort mortality study of iron ore (hematite) miners in Minnesota. 7 Occup Med 1985;27:507-17.

47 Collen MF. A study of pneumonia in shipyard workers, with special reference to welders. F Ind Hyg Toxicol 1947;29:113 22 .

48 Cotes JE, Feinmann EL, Male VJ, Rennie RS, Wickham CAC. Respiratory symptoms and impairment in shipyar welders and caulker/burners. Br f Ind Med 1989;46:292 301 .

49 Fawer RF, Ward Gardner A, Oakes D. Absences attributed to respiratory diseases in welders. $\mathrm{Br} \mathcal{F}$ Ind Med 1982;39. to respiratc

50 Fogh A, Frost J, Georg J. Respiratory symptoms and pulmonary function in welders. Ann Occup Hyg 1969;12:213-8.

51 McMillan GHG, Plethybridge RJ. A clinical radiological and pulmonary function case-control study of 135 dockyard welders aged 45 years and over. 7 Soc Occup Med 1984;34:3-23.

52 Chinn DJ, Cotes JE, El Gamal FM, Wollaston JF. Respiratory health of young shipyard welders and other tradesmen studied cross sectionally and longitudinally Occup Environ Med 1995;55:33-42. 